\title{
No association between bronchial asthma and HLA-DRB1, -DQB1 alleles in the Slovak population
}

\author{
Dzurilla $\mathrm{M}^{1}$, Vrlík $\mathrm{M}^{2}$, Homolová $\mathrm{M}^{1}$, Buc, $\mathrm{M}^{1}$ \\ Department of Immunology, Comenius University School of Medicine, Bratislava, Slovakia. dzurilla@gmail.com
}

\begin{abstract}
: 109 patients (62 boys/men and 47 girls/women) suffering from bronchial asthma induced by pollen allergens were typed for HLA-DRB1 and -DQBI alleles, respectively, by a low resolution SSP technique. Frequencies of DRB1 alleles varied from $0.5 \%$ to $16.1 \%$. The most frequent was HLA-DRB1*11 (16.1\%), the least frequent HLA-DRB1*09 (0.4\%). Occurrence rates of HLA-DQB1 alleles ranged from $2.3 \%$ to $37.2 \%$, HLA-DQB ${ }^{*} 03$ being the most frequent $(37.2 \%)$ and DQB $1{ }^{*} 04$ stood on the opposite pole $(2.3 \%)$. By comparing to occurrence rates in the healthy population, no statistically significant differences were disclosed (Tab. 2, Ref. 16). Full Text in PDF www.elis.sk.

Key words: bronchial asthma, genetic predisposition, HLA-DQB1, HLA-DRB1.
\end{abstract}

Bronchial asthma is a common immune-mediated disorder characterised by reversible airway inflammation, mucus production, and variable airflow obstruction with airways hyper-responsiveness (1). It runs in families and has a clear hereditary component (2). Genome-wide screens for allergy and asthma have disclosed many susceptibility genes, including $2 \mathrm{q}, 5 \mathrm{q}, 6 \mathrm{p} 12 \mathrm{q}$, and $12 \mathrm{q}(3,4)$. Among them, chromosome $5 \mathrm{q} 3133$ is of particular interest because it contains a cluster of genes, e.g. interleukin IL-4, IL-13, CD14, ADRB2 ( $\beta 2$ adrenergic receptor, and SPINK5 (serine peptidase inhibitor, Kazal type 5 ), respectively $(3,5)$ that are likely to be involved in asthma pathogenesis $(4,6)$.

Other potential candidate genes are in chromosome 6p21, which contains the extensively studied human leucocyte antigen (HLA) genes. HLA molecules play an important role in induction of immune response. They present immunogenic peptides to $\mathrm{T}$ lymphocytes, the key cells in the induction of the immune response, including hypersensitivity type 1 reactions. This principal role enabled them to become markers of many disorders, especially those of autoimmune character $(7,8)$. There are also some reports on associations of HLA alleles with asthma; however, the results are inconsistent. Some studies support the association [9, $10)$ while others do not $(11,12)$. Our own study has indicated an association between HLA-DRB1*13:01 and pollen allergy (13). These inconsistencies led us to investigation of the distribution of

${ }^{1}$ Department of Immunology, Comenius University School of Medicine, Bratislava, and ${ }^{2}$ Martin Immunology Centre, Martin, Slovakia

Address for correspondence: M. Dzurilla, MD, Department of Immunology, Comenius University School of Medicine, Odborarske namestie 14, SK-813 72 Bratislava 1, Slovakia.

Acknowledgments: This study was supported by funding from the grant of Agency of Ministry of Education of Slovak Republic VEGA 1/0574/10.
HLA-DRB1 and -DQB1 alleles, respectively, among asthmatics and evaluation of their possible correlation with susceptibility or resistance to asthma.

\section{Materials and methods}

109 patients ( 62 boys/men and 47 girls/women) suffering from bronchial asthma induced by grass pollen allergens were investigated. The age of patients varied from six to 55 years at the time of investigation, the mean was 21.9 years. The diagnosis of the bronchial asthma was based on anamnesis, clinical investigation by the WHO GINA (The Global Initiative for Asthma) criteria, skin prick tests (allergens tested were in a standardised mixture; Alyostal, Stallergenes, France) and by specific IgE antibodies investigation (HYCOR HYTEC ${ }^{\text {TM }} 288$ system). The control group for DRB1 typing comprised 130 and that for DQB1 typing 143 unrelated healthy individuals from Bratislava and its neighbourhood (14); controls were not selected to match the cases, they were just randomly selected. However, from the point of the genetic background, both the investigated and control groups are homogenous, they belong to Slovak population.

HLA typing was performed by a low-resolution PCR-SSP method using the GenoVision primer sets (Olerlup SSPTM AB Sweden) as reported previously (14). Briefly, DNA was extracted from whole blood using a modified salting out procedure. Genomic DNA was amplified by PCR with sequence-specific primers. PCRamplification was performed as recommended by the manufacturer. The polymerase chain reaction (PCR) amplifications were carried out in a $\mathrm{C} 1000$ Thermal Cycler (BIO-RAD), the PCR products were separated on $1.5 \%$ agarose gel stained with ethidium bromide for 20 minutes at $10 \mathrm{~V} / \mathrm{cm}$ and the gel was UV-photographed. Odds ratios (OR) were calculated according to Woolf's formula and the p-values defined by Fisher's exact test. 
Tab. 1. Frequencies of DRB1 alleles in bronchial asthma patients and healthy population.

\begin{tabular}{|c|c|c|c|c|c|c|c|}
\hline \multirow[t]{2}{*}{ DRB1 } & \multicolumn{2}{|c|}{$\mathrm{AB}$} & \multicolumn{2}{|c|}{ Controls } & \multirow[b]{2}{*}{$\mathrm{p}$} & \multirow[b]{2}{*}{ OR } & \multirow[b]{2}{*}{$95 \% \mathrm{CI}$} \\
\hline & n- & $\%$ & n- & $\%$ & & & \\
\hline$* 01$ & 20 & 9.2 & 19 & 7.3 & 0.5042 & 1.2810 & $0.665-2.468$ \\
\hline$* 03$ & 26 & 11.9 & 25 & 9.6 & 0.4584 & 1.2730 & $0.712-2.276$ \\
\hline$* 04$ & 22 & 10.1 & 29 & 11.2 & 0.8785 & 1.0550 & $0.577-1.930$ \\
\hline$* 07$ & 29 & 13.3 & 37 & 14.2 & 0.7916 & 0.9248 & $0.548-1.561$ \\
\hline$* 08$ & 12 & 5.5 & 12 & 4.6 & 0.6793 & 1.2040 & $0.530-2.737$ \\
\hline *09 & 1 & 0.5 & 1 & 0.4 & 1.0000 & 1.1940 & $0.074-19.21$ \\
\hline$* 11$ & 35 & 16.1 & 53 & 20.4 & 0.2379 & 0.7470 & $0.466-1.196$ \\
\hline *12 & 3 & 1.4 & 4 & 1.5 & 1.0000 & 0.8930 & $0.198-4.035$ \\
\hline$* 13$ & 23 & 10.6 & 21 & 8.1 & 0.4274 & 1.3420 & $0.721-2.498$ \\
\hline$* 14$ & 8 & 3.7 & 7 & 2.7 & 0.6043 & 1.3770 & $0.491-3.861$ \\
\hline$* 15$ & 27 & 12.4 & 32 & 12.3 & 1.0000 & 1.0070 & $0.583-1.741$ \\
\hline$* 16$ & 10 & 4.6 & 14 & 5.4 & 0.8341 & 0.8448 & $0.368-1.942$ \\
\hline
\end{tabular}

Tab. 2. Frequencies of DQB1 alleles in bronchial asthma patients and healthy population.

\begin{tabular}{|c|c|c|c|c|c|c|c|}
\hline \multirow[t]{2}{*}{ DQB1 } & \multicolumn{2}{|c|}{$\mathrm{AB}$} & \multicolumn{2}{|c|}{ Controls } & \multirow[b]{2}{*}{$\mathrm{p}$} & \multirow[b]{2}{*}{ OR } & \multirow[b]{2}{*}{$95 \% \mathrm{CI}$} \\
\hline & $\mathrm{n}-$ & $\%$ & n- & $\%$ & & & \\
\hline$* 02$ & 47 & 21.6 & 60 & 21.0 & 0.9126 & 1.0350 & $0.673-1.592$ \\
\hline$* 03$ & 81 & 37.2 & 98 & 34.3 & 0.5121 & 1.1340 & $0.785-1.638$ \\
\hline *04 & 5 & 2.3 & 13 & 4.5 & 0.2282 & 0.4930 & $0.173-1.405$ \\
\hline$* 05$ & 43 & 19.7 & 56 & 19.6 & 1.0000 & 1.0090 & $0.648-1.572$ \\
\hline$* 06$ & 42 & 19.3 & 59 & 20.6 & 0.7371 & 0.9181 & $0.590-1.429$ \\
\hline
\end{tabular}

$\mathrm{AB}$ - bronchial asthma , $\mathrm{CI}$ - confidence interval, $\mathrm{OR}$ - odds ratio, $\mathrm{n}$ - number

\section{Results and discussion}

Thirteen DRB1 alleles were typed. Their frequencies varied from $0.5 \%$ to $16.1 \%$. The most frequent was HLA-DRB $1 * 11$ and on the opposite spectrum stood HLA-DRB $1 * 09$. When compared to occurrence rates in the healthy population, we found no statistically significant differences (Tab. 1). A similar situation was observed with HLA-DQB1 alleles. Five alleles were determined and their frequencies varied from $2.3 \%$ to $37.2 \%$. The highest occurrence rate showed HLA-DQB $1 * 03$ and DQB $1 * 04$ was the least frequent (Tab. 2).

Unlike a single-gene disease, most diseases, including bronchial asthma, are multi-genetic in nature $(6,15)$. Because of unequivocal role of HLA molecules in induction and regulation of the immune response, one approach how to contribute to the comprehension of the disease development has been to look for associations between HLA alleles and diseases. There are many reports on associations of HLA alleles with asthma, which include various DRB1 and DQB1 alleles (9); out of them, the association between childhood asthma and DRB $1 * 03$ seems to be the most relevant $(9,16)$. However, some studies report no associations $(11,12)$. Our previous study indicated an association between HLA-DRB1*1301 and pollen allergy (13), which was, however, not confirmed in the present study. The contradictory results of our previous and present studies result probably from the small cohort investigated previously - the patients group represented 30 patients only; moreover, out of them, eight patients suffered from asthma bronchiale, others suffered from allergic rhinoconjuctivitis. No association between asthma bronchiale and the investigated HLA alleles in the present study can also result from relatively non-homogenous cohort of patients, as the age of patients varied from six to 55 at the time of diagnosis establishment.

Discrepancies reported by various investigators can be explained by the fact that unknown number of genes influence asthma bronchiale, with each gene depending on unknown number of alleles or haplotypes. In addition, different genes may affect different populations having different genetic backgrounds or environmental exposures.

Although we have investigated more than 100 patients, we still consider the results as preliminary. We intend to investigate a larger group of patients and to look for an association with cytokine gene polymorphisms.

\section{References}

1. Buc M, Dzurilla M, Vrlik M, Bucova M. Immunopathogenesis of bronchial asthma. Arch Immunol Ther Exp (Warsz) 2009; 57 (5): 331-344.

2. Los H, Postmus PE, Boomsma DI. Asthma genetics and intermediate phenotypes: a review from twin studies. Twin Res 2001; 4 (2): 81-93.

3. Guerra S, Martinez FD. Asthma genetics: from linear to multifactorial approaches. Annu Rev Med 2008; 59: 327-341.

4. Vercelli D. Discovering susceptibility genes for asthma and allergy. Nat Rev Immunol 2008; 8 (3): 169-182.

5. Ober C, Hoffjan S. Asthma genetics 2006: the long and winding road to gene discovery. Genes Immun 2006; 7 (2): 95-100.

6. Moffatt MF, Gut IG, Demenais F, Strachan DP, Bouzigon E, Heath S, von Mutius E, Farrall M, Lathrop M, Cookson WO. A large-scale, consortium-based genomewide association study of asthma. N Engl J Med 2010; 363 (13): 1211-1221. 
7. Buc M. The major histocompatibility complex in man. Folia Biol (Praha) 1995; 41 (3-4): 119-122.

8. Shiina T, Inoko H, Kulski JK. An update of the HLA genomic region, locus information and disease associations: 2004. Tissue Antigens 2004; 64 (6): 631-649.

9. Juhn YJ, Kita H, Lee LA, Smith RW, Bagniewski SM, Weaver AL, Pankratz VS, Jacobson RM, Poland GA. Childhood asthma and human leukocyte antigen type. Tissue Antigens 2007; 69 (1): 38-46.

10. Munthe-Kaas MC, Carlsen KL, Carlsen KH, Egeland T, Haland G, Devulapalli CS, Akselsen H, Undlien D. HLA Dr-Dq haplotypes and the TNFA-308 polymorphism: associations with asthma and allergy. Allergy 2007; 62 (9): 991-998.

11. Moffatt MF, Schou C, Faux JA, Abecasis GR, James A, Musk AW, Cookson WO. Association between quantitative traits underlying asthma and the HLA-DRB1 locus in a family-based population sample. Eur J Hum Genet 2001; 9 (5): 341-346.
12. Young RP, Dekker JW, Wordsworth BP, Schou C, Pile KD, Matthiesen F, Rosenberg WM, Bell JI, Hopkin JM, Cookson WO. HLADR and HLA-DP genotypes and immunoglobulin E responses to common major allergens. Clin Exp Allergy 1994; 24 (5): 431-439.

13. Buc M, Fazekasova H, Shawkatova I, Hrubisko, M. Pollen allergy to Amb-allergens and class II HLA alleles in the Slovak population. In: EFIS 2000. Bologna, Monduzzi, 61-65; 2000.

14. Cechova E, Fazekasova H, Ferencik S, Shawkatova I, Buc M. HLADRB1, -DQB1 and -DPB1 polymorphism in the Slovak population. Tissue Antigens 1998; 51 (5): 574-576.

15. Bosse Y, Hudson TJ. Toward a comprehensive set of asthma susceptibility genes. Annu Rev Med 2007; 58: 171-184.

16. Hanchard NA, Jacobson RM, Poland GA, Juhn YJ. An assessment of the association between childhood asthma and HLA DRB $1 * 03$ using extended haplotype analysis. Tissue Antigens 2010; 76 (6): 491-494.

Received March 11, 2011. Accepted August 18, 2012. 